Article

\title{
Use of Traditional Weather/Climate Knowledge by Farmers in the South-Western Free State of South Africa: Agrometeorological Learning by Scientists
}

\author{
Gugulethu Zuma-Netshiukhwi ${ }^{1}$, Kees Stigter ${ }^{2,3} *$ and Sue Walker ${ }^{4}$
}

1 South African Weather Service, Bram Fischer International Airport, Private Bag X20562,

Bloemfontein 9300, South Africa; E-Mail: gugunc27@yahoo.com

2 Department of Soil, Crop and Climate Sciences, Faculty of Natural and Agricultural Sciences, University of the Free State, Bloemfontein, South Africa

3 Agromet Vision, Groenestraat 13, Bruchem 5314 AJ, The Netherlands

4 Section Agrometeorology, Department of Soil, Crop and Climate Sciences, Faculty of Natural and Agricultural Sciences, University of the Free State, P.O. Box 339, Bloemfontein 9301, South Africa; E-Mail: walkers@ufs.ac.za

* Author to whom correspondence should be addressed; E-Mail: cjstigter@usa.net; Tel.: +31-418-642-906.

Received: 3 September 2013; in revised form: 29 September 2013 / Accepted: 25 October 2013 / Published: 13 November 2013

\begin{abstract}
The variety of natural indicators, associated with weather forecasting and climate prediction, as used by farmers in the South-Western Free State province of South Africa, is described. Most farmers in this area were not familiar with the application of weather forecasts/climate predictions for agricultural production, or with other science-based agrometeorological products. They relied almost fully on their experience and traditional knowledge for farming decision making. The indicators for traditional knowledge are demonstrated here in broad terms, relying on the stories and indications from observations and years of experience of their use by the farmers. These means of engagement with the natural environment, are skills not well understood by most scientists, but useful to the farmers. They range from the constellation of stars, animal behavior, cloud cover and type, blossoming of certain indigenous trees, appearance and disappearance of reptiles, to migration of bird species and many others. It is suggested that some short-term traditional forecasts/predictions may be successfully merged with science-based climate predictions. The traditional knowledge and its use, reported on in this paper, is what scientists learned from farmers. Berkes was right that scholars have wasted too much time and effort on a
\end{abstract}


science versus traditional knowledge debate; we should reframe it instead as a science and traditional knowledge dialogue and partnership. The complications of a changing climate make this even more necessary.

Keywords: farmer traditional knowledge; agrometeorological learning; weather/climate forecasts/predictions; science-based agrometeorological advisories/services

\section{Introduction}

\subsection{General}

Scientists and local traditional farmers use different methods to forecast weather conditions and predict a likely behavior of climate in the planting season. Agrometeorologists have, in the past few decades, developed different types of science-based knowledge, to better cope with climate variability, but, operationally, this leaves for farmers much to be desired. On the other hand, traditional farmers use observations of nature as guidance for agricultural activities to be undertaken. This paper aims at documenting traditional indicators and their application in agricultural decision-making. In the south-western Free State province of South Africa, the use of traditional weather/climate knowledge is still prominent for resource-poor farmers, but less common for commercial farmers [1]. Resource poor farmers are defined here as subsistence farmers without sufficient resources and access to such resources for an acceptable living from farming. Commercial farmers are farmers that earn an acceptable living from trading farm products.

The objective of this paper is to highlight and document natural indicators in indigenous knowledge used by these farmers to forecast weather phenomena, predict seasonal climate behavior, and use them in their decisions on agricultural activities. This study's purpose also was to make some agrometeorological advisories and services accessible to resource poor as well as commercial farmers within the study area, and to observe qualitatively improvements in production [1].

Agricultural production in the South-Western Free State is both under irrigation (for a relatively small area) and as dry rainfed agro-ecosystems. The study area is characterized as a semi-arid area, which certainly explains its unpredictable and inconsistent rainfall at any time throughout the year. There is a growing interest from scientists to create platforms in such areas, for sharing and exchanging of knowledge between advisors in and service providers for agricultural decision making and end users such as farmers, particularly covering their present vulnerabilities. In [2], an example in agrometeorological learning tells how some scientists in Indonesia regularly meet farmers to jointly address questions related to such vulnerabilities

In our case study presented here, such meetings preceded the introduction of these farmers to applied agrometeorological and other science-based knowledge for improved agricultural decision making [1]. Because of principal differences in scientific derivation and use, we apply the word "forecast" for short term weather conditions, of not more than one week, and the word "prediction" for (in our case utmost seasonal) climate conditions. 
Traditional knowledge is explained as the knowledge of a group or a community from a particular area, based on their environmental understanding, interacting with nature and experiences within their area $[3,4]$. In our research, emphasis has been on what scientists learned from this traditional knowledge. What farmers learned is discussed, but was only qualitatively assessed. How successfully they used which science-based knowledge, and how, must be parts of follow-up research. Quite some traditional climate indicators suffer from climate change, as they were based on no longer existing climate behavior, for example related to temperatures and rainfall distributions that have substantially changed [1]. Only for climate prediction we hint at the possible integration of relatively short-term traditional forecasting/prediction, and seasonal climate scenarios scientifically predicted.

Although in agrometeorology interest in traditional knowledge is far from new (e.g., [5-7], where extensive examples on mulching, shading and other traditional microclimate management, and manipulation were reviewed), there is among others a still growing appreciation of the value of traditional knowledge on several aspects of biodiversity [8,9]. This knowledge is valuable not only to those who depend on it in their daily lives, but to modern industry and agriculture as well. Many widely used products, such as plant-based medicines, health products and cosmetics, are derived from traditional knowledge. Other valuable products based on traditional knowledge include agricultural and non-wood forest products and handicrafts [1].

The authors were inspired by the richness of traditional knowledge discovered from the farmers during semi-structured and structured interviews conducted with the farmers [1]. Traditional knowledge indicators have been practiced by farmers for crop and animal production (see the many examples in this paper) as well as in traditional agroforestry (e.g., [7,10]). Such indicators have, this way, made significant contributions towards more sustainable development, due to the resource management involved. Open recognition of the value of traditional knowledge contributed to building the very necessary relation of mutual trust that is necessary in the type of extension we practiced [1,2,11]. Our findings discussed below show not only the use and usefulness of such traditional knowledge, but also its limitations for the further increase and protection of production, under conditions of a changing climate.

\subsection{Some Details on Traditional Knowledge in Weather and Climate}

Long before the initiation of modern scientific methods for weather forecasting and climate prediction, farming continued successfully, with the exception of regular disasters (e.g., [11-13]). Farmers utilized traditional ways and indicators of rainfall forecasting/prediction. Compared to the dominant industrialized societies, in which activities in the last 200 years or so have caused most of the climate impacts currently observed, indigenous people living on their traditional lands bear little responsibility for current and future projected consequences of a changing climate. Despite this, they are likely to suffer the most from direct and indirect climate change, due to their close connection to the natural world and their reduced social-ecological resilience. The latter is a consequence of centuries of oppressive policies imposed on them by dominant non-indigenous societies [14]. However, the 'green revolution', as a source of welcome rural progress, was already gaining steam in the industrializing countries in the 19th century. It may be argued that the real green revolution was not 
so much a technological one but, rather, the rapid diffusion of useful scientific knowledge across large parts of the Southern hemisphere [15], which did not include much of Sub-Saharan Africa [13].

This question of timing in progress redirects attention to the role of state policy in overcoming certain market imperfections. Asian governments channeled substantial public resources into the development of rural infrastructure and credit facilities. They subsidized and coordinated technical support to farmers. They offered infant-industry protection to emerging fertilizer industries; in some cases, Asian governments went as far as to distribute micro-packages of hybridized seed and fertilizer to encourage farmers to grow new cultivars [15].

Virtually none of this progress happened in Africa, where much of the traditional knowledge continued to be applied [13]. Traditional rainfall forecasting/prediction refers to indicators that are locally used to interpret weather/climate conditions to be expected. Traditional rainfall forecasts/ predictions differ across communities, cultural background, and environment around the farm [16,17]. In South-Western Free State and Kwa-Zulu Natal (both in South Africa) as well as Western Kenya, inhabitants use birds, toads, and white ants to predict the summer season and onset of rains as well as temperatures ranging from something like $18{ }^{\circ} \mathrm{C}$ to $26{ }^{\circ} \mathrm{C}[18,19]$. While in the North-Eastern Brazil they use the appearance of crickets. In Tanzania, they look at the behavioral patterns of birds and mammals [20].

According to [21,22], activities of arthropods, such as fleas, cockroaches, houseflies, spiders and many others are indications for the arrival of the summer season in Japan. Even the local names of invertebrates are figuratively indicative of a particular season. These arthropods have been noticed by farmers to be abundant during the summer season. Farmers for example stated that cockroaches disappear during winter season. It was also observed that traditional climate prediction and contemporary seasonal predictions were thought to be both useful and dependable, by resource poor as well as commercial farmers [22].

\subsection{Climate Vulnerabilities}

Do farmers observe that the climate is changing and are they aware of their vulnerabilities? Fieldwork in Uganda showed that farmers perceived regional climate to have changed in the past 20 years. In particular, farmers felt that temperature had increased and seasonality and variability had changed, with the first rainy season between March and May becoming more variable. Farmers reported detailed accounts of climate characteristics during specific years, with recent droughts in the late 1990s and late 2000s confirming local perceptions that there has been a shift in climate towards more variable conditions that are less favorable to production [23]. Farmers in Southern Uganda seek information to anticipate the interannual variability in the timing and amount of precipitation, a matter of great importance to them since they rely on rain-fed agriculture for food supplies and income. The four major components of their knowledge system are: (1) longstanding familiarity with the seasonal patterns of precipitation and temperature, (2) a set of local traditional climate indicators, (3) observation of meteorological events, and (4) information about the progress of the seasons elsewhere in the region. This system of indigenous knowledge leads farmers to participate as agents as well as consumers in programs that use modern climate science to plan for and adapt to climate variability and climate change [24]. 
More than a decade ago, Stigter et al. [25], based on a paper presented at a World Meteorological Organization (WMO), Commission for Agricultural Meteorology (CAgM), workshop in Slovenia in 2002, were among the first to write, from within the agrometeorology, on the use of traditional methods and indigenous technologies for coping with climate variability. The paper reviews the options that Low External Inputs Sustainable Agriculture (LEISA) farmers have in coping with risk of agrometeorological and agroclimatological calamities. This is based on the role that the pertinent meteorological/climatological parameters and phenomena play as limiting factors in agricultural production, and the expectations on their variability. Subsequently, local case studies are given as examples of preparedness strategies to cope with (i) variable water/moisture flows, including mechanical impacts of rain and/or hail, (ii) variable temperature and heat flows, including fires, and (iii) fitting cropping periods to the varying seasons, everywhere, including related phenomena as appropriate [25]. Much more recently, Meinke [26] tabled mitigation and adaptation actions with warnings on problems and opportunities that may occur locally, with potentially conflicting goals and many ill-defined individual outcomes that are hard to measure.

Rainfed production is highly dependent on the availability of supplementary water to sustain crop growth and development (e.g., [6,27]), because of rainfall variability and amounts received [28]. However, in the study area, rainfed agriculture is practiced by most farmers, worsening poverty by this dependence on the local rainfall. Increasing food insecurity is linked to declining levels of agricultural productivity $[29,30]$. Therefore, dependency on traditional knowledge and rainfed agriculture in the South-Western Free State renders the agricultural status also there highly vulnerable to increasing climate variability. This is exemplified by the seasonal rainfall distribution, shifts of rainfall onset and cessation, frost onset, and the occurrence of other extreme weather/climate events. It was clearly noted how vulnerable most farmers were, but it was also realized that farmers have their ways to guide farm level decision making. According to [31], provision and proper utilization of science-based agrometeorological knowledge could guide farm level decisions on crop suitability, cultivar selection, choice of cropping systems, planting dates as well as planting densities. Climate disaster vulnerability for the study region is dealt with further on in this paper.

Rather early, Patt and Gwata [32] wrote that making forecasts useful to decision-makers, especially subsistence farmers in developing countries, remained a significant challenge. They discussed a set of six constraints limiting the usefulness of forecasts: credibility, legitimacy, scale, cognitive capacity, procedural and institutional barriers, and available choices. They identified how these constraints had in fact limited forecast use, and proposed means of overcoming them. Given low skills of present day predictions [13], we may start simply, for example, with having better water management based on such seasonal climate forecasts, improved infrastructure, and adapted varieties [26,33,34].

Simelton et al. [35] did (1) identify southern African farmers' perceptions of rainfall, rainfall variations, and changes; (2) examine the nature of meteorological evidence for the perceived rainfall variability and change; (3) document farmers' responses to rainfall variability; and (4) discuss why discrepancies may occur between farmers' perceptions and meteorological observations of rainfall. Most farmers perceived that the rains used to start earlier and end later. Indeed, a high inter-annual variability in the timing of the onset was observed alongside an increasing number of dry days and declining amounts of rainfall at the onset and cessation of precipitation. Some rainfall patterns were associated with El Niño-Southern Oscillation (ENSO) fluctuations and larger-scale changes. These 
findings suggest that scientists, policymakers, and developers of climate adaptation projects need to be more in tune with farmers' and extension workers' understandings of how weather is changing, in order to improve adaptation policy formulation and implementation [35]. Organizing Science Field Shops would make this possible [2,36].

\subsection{Other Vulnerabilities}

With respect to African food farming of resource poor farmers, much of it still can better be described as a coping strategy rather than as remunerative enterprise that rewards innovation and professionalism [37]. Thus, we should not continue the so-often-used terminology of "risk management" by African farmers, but we should say that, in their vulnerability, they are "coping with risks" [13]. The challenge is not only to design new coping strategies, but also to bring about institutional transformations within which such strategies would become rational for farmers [38]. Vulnerability has emerged as a cross-cutting theme in research on the human dimensions of global environmental change. Yet, vulnerability to climate change has traditionally been studied in isolation from other stressors, including structural changes associated with economic globalization. It has been acknowledged that exposure to multiple stressors is a real concern, particularly in developing countries, where food security is influenced by political, economic, and social conditions, in addition to climatic factors [39]. There are two competing interpretations of vulnerability in the climate change literature. The first interpretation, which can be referred to as the "end point" approach, views vulnerability as a residual of climate change impacts minus adaptation. The second interpretation, which takes vulnerability as a "starting point", views vulnerability as a general characteristic generated by multiple factors and processes [40].

Although, from the livelihood point of view, the latter interpretation is needed, in line with [39], for this present paper on traditional weather/climate knowledge of and use by farmers, the former interpretation will do; with the comment that adaptation remains dependent on other factors than weather and climate only. It goes too far for this paper to consider this any further. However, it remains important to realize complexity of vulnerability in heterogeneous rural societies as South Africa. Examining rural livelihoods on both sides of the United States-Mexico border, looking beyond single agricultural systems, crossing borders and listening to rural producers in this semi-arid environment, offers a more complete picture of how differences in access to resources, state involvement, class and ethnicity result in drastically different vulnerabilities within a similar biophysical context [41].

Due to our emphasis, in line with the thesis on which this paper is largely based [1], on identifying and discussing with farmers their use of traditional knowledge with agrometeorological components, the exchange of knowledge between farmers and scientists has got little attention so far. This is mainly due to the fact that we have not yet studied what scientists did or could have done with what they learned from the farmers, neither have we made a detailed quantitative study of the benefits that farmers gained from the various science-based knowledge that we provided in the course of time.

The literature reviewed in [42] suggests that what we worked on with our farmers is indigenous knowledge (IK). This IK excluded traditional ecological knowledge (TEK), while it is much of the literature on TEK that deals with similarities and differences between Western science and traditional 
knowledge [42]. In addition, [43] revealed that there exists a diversity of local or traditional practices for ecosystem management. These include multiple species management, resource rotation, succession management, landscape patchiness management, and other ways of responding to and managing ecosystems (see also [13]). However, our dialogues with the Free State farmers were not in this terminology but, in that of more classic phenomenological issues, such as in phenology, as parts of agrometeorology. The work for [1] started in 2007. Should we have to start now, we would make use of the new insights in the conviction that food production can increase, but at the same time can be sustainable through the ecological intensification of current agriculture, making intensive and smart use of the natural functionalities that ecosystems offer [44].

Although Ristroph [45] considered the benefits of using community knowledge (see also [10]), as well as obstacles to collecting this knowledge and integrating it with Western science, no agrometeorology was considered there. A few well known scientists (e.g., [46]) have combined research and collaborative learning approaches to enable 'bottom-up' strategies for improved environmental and social wellbeing (see also [2] and case studies in [36]). Möller [46] complemented this by ongoing advice to national-level policy-makers for improved management of both production landscapes and Protected Natural Areas. Findings indicate that also in the Southeast USA (Georgia) farmers' coping with risks associated with climate variability is embedded within a broad array of social factors, including subjective construction of social and personal identities, goals, and values [47].

These cultural contexts affect the ways that farmers interpret and might apply seasonal climate forecasts to agricultural decisions [47]. These findings also indicate that, rather than simply acting as a technical information input, seasonal climate predictions, and those making these predictions, must gradually work their way into farmers' trusted social networks, before their potential as tools for coping with risk will be realized. Furthermore, while seeking to produce scientific information to support farmers' adaptive practices, scientists themselves must adapt their own practices to better fit a coproduction of knowledge approach [47]. This is in line with experience reported from Indonesia [2,11,36], and our preliminary experience in South Africa also fits these important findings [1].

\subsection{Details of the Approach}

The learning platforms were established in selected towns within the south-western Free State. Study groups were established which met on a monthly basis. The study groups entailed commercial and resource poor farmers, and other stakeholders such as extension agents from the Department of Agriculture, Forest and Fisheries, representatives from South African banks, whose role was to educate farmers on financial management and on how to access agricultural production loans from banks, and other institutions [1]. It was a real learning experience for a researcher to conduct an agrometeorological study in the Southwestern Free State, and to try to create a platform for information exchange with farmers. During this interaction, it was observed that the resource poor farmers only relied on their local knowledge. They learned on various subjects related to weather forecasting and climate predictions. On the other hand, researchers learned on farmer's indigenous knowledge related to weather and climate and its applications for fields and crops.

Farmers were delighted to share their ideas with the researchers, with the intention to learn on matters that they had never worked with before: on scientific weather forecasting, climate prediction 
and other use of probabilities, other (science-based) weather/climate knowledge and its application in crop and animal production as well as agroforestry. Progressively, new knowledge was brought to farmers and their general handling of crop and animal production were enriched with new science-based knowledge (see also [2] on how this fits new perceptions of agricultural extension). We now focus on discussing details of the knowledge on traditional indicators and of famers' many years of experience and observations.

Interactions in study groups, and meetings with the farmers, were events where joint creation of knowledge took place (see also [48]). Researchers and farmers were interacting from completely different perspectives, to create and transfer knowledge and shared meanings for change [11]. In this case, both parties and individuals play a crucial role in establishing their own learning and findings through study groups and other qualitative participatory methodologies [11]. Farmers were bold in learning on applications of agrometeorological products (which are prepared by Weather Services, Universities and Research Institutes from their research results), and they were actively sharing their knowledge, experiences and enthusiasm to incorporate agrometeorological advisories/services (which are products made more client friendly and operational by product intermediaries [2,36]) into their daily agricultural activities and decision-making. However, emphasis in this paper is on how they used their traditional knowledge in decision making and also on the limitations of that knowledge. Scientists were learning on farmers' perspectives, and only started to form ideas on how to combine the two fields of knowledge successfully.

In summary, the authors describe a contemporary topic relevant to the understanding of traditional knowledge systems for environmental management in agricultural production. Empirically, the paper describes farmers' traditional forecasting systems in the South-Western Free State of South Africa. Methodologically, the article demonstrates the importance of qualitative participatory tools for weather and climate knowledge exchange. Theoretically, the work highlights the importance of sharing traditional and scientific weather/climate knowledge among different stakeholders, with emphasis on what scientists learned from farmers. Where not explicitly mentioned, no distinction was made within groups of farmers between resource poor and commercial farmers.

\section{Conditions of the Free State situation}

\subsection{General}

Farming systems ideally designate a set of agricultural activities, organized while preserving land productivity and environmental quality, and while maintaining desirable levels of biological diversity and ecological stability [49]. Many farms in the South-Western Free State have a general similarity in crop and livestock production practices and methods of production. Farmers view their farms, whether resource poor or commercial, as a system in its own right. An individual farm unit is unique, arising from resource support and family background.

In Southern Africa, including the Free State, climate inconsistency is the core determining cause in productivity variability and the sustainability of farming systems [50]. Amongst others, soil degradation, decreasing water resources, and changes in climate, are also major impediments to sustainability of agricultural development. Farmers have relied on nature to determine the season of the 
year, and traditionally, the growing season is the period of the year which is determined predominantly by climate and crop requirements. It depends on the location, temperature, photoperiod and rainfall, as the most critical environmental factors [13].

Farmers are familiar with the relations between weather, crop suitability, crop selection and planting schedule in a particular season. When and what to plant is determined by integrated weather/climate indicators and interpreting indicators within the environment. These traditional weather-related indicators, and this animal behavior, are used as guidance for farmer choices on their farming activities. We cannot be ignorant to indicators used by the farmers. We must learn from it, since farmers have survived for decades and decades using local knowledge [13]. Seasonal prediction in indigenous knowledge was culturally conserved and passed on from generation to generation. Farmers made use of this knowledge in deciding on crop variety, planting dates, and other coping strategies, so as to produce good yields.

\subsection{Present Situation}

However, farmers are now more or less forced to also learn the application of scientific information, since, due to climate change and other changes, some of the traditional indicators have disappeared from the ecosystem. For example, there are indigenous trees which were cut down for fuel, and bird species that migrated to other places [51]. The major challenge for the researchers was how to combine indigenous knowledge and science-based products, and to actually train the farmers in interpreting and using the latter.

Farmers' vulnerability to climate abnormality often is also caused by lack of resources and support systems, as some have no means to adapt rapidly [52]. Adaptation to increasing climate variability and to other consequences of climate change in Africa $[33,34,53]$ is essential to minimize consequences of new climate risks. Improved preparedness is essential for more sustainable crop and animal production under these new conditions. Therefore, introducing agrometeorological products to farmers creates a platform for the on-farm development of a new range of different adaptation strategies for different agricultural enterprises, tailor-made [1]. With the provision of weather forecasts for agriculture, of seasonal climate predictions of sufficient skill and of other science-based advisory products, critical decisions can be improved (e.g., [26]).

Also commercial farmers use traditional indicators for rainfall forecasting/prediction, although they depend mostly on science-based products. From the focus group discussions and transect walks that took place during the diagnostic phase of this work, it was found that science based agrometeorological products were not popular with those just below $90 \%$ of farmers that had no access to such products [1]. After identifying various difficulties confronted by the farmers to be successful in agricultural business, it became a priority to introduce different types of weather forecasting and climate prediction information as well as other science-based agrometeorological advisories to the farmers.

However, the science based forecasts/predictions are difficult to interpret and to incorporate into decision making by both commercial and resource poor farmers. Such weather and climate products as broadcasted on a daily basis on radio and television are not sufficient to guide farmers in strategic long-term planning. However, these products could be helpful to decide on tactical planning, if they were better geared to agricultural use. 


\subsection{Particular Backgrounds for Combining Traditional and Scientific Knowledge}

What indicators were used to forecast rainfall? For example, should farmers recognize a change in behavior and/or movement of cows and calves in the veld, together with accumulating clouds, it was considered an indication that rains would fall in a few hours or a day's time. It is very critical to understand indigenous knowledge prior to introducing scientific knowledge to farmers [54]. This is more urgent now, under conditions of a changing climate. Traditional methods applied by commercial and resource poor farmers are later on presented, identifying existing channels of knowledge dissemination, and determining from a case study how we can combine traditional and science-based weather forecasting and climate prediction.

In the South-Western Free State, farmers practice mixed farming systems with crops, livestock and agroforestry. It was explored how the farmers use which traditional weather/climate indicators for short-term and long-term planning for the rainy season. The absence of these signals, at times when expected well in advance, is a weakness and can be seen as unreliable. However, farmers are faced with lots of challenges and have to adapt. The most common and threatening weather and climate hazards are floods, drought, strong dry winds, black frost and hailstorms. For example, floods may be due to overflowing of dams and river banks, causing damages to field crops by causing water logging. Early frost could destroy flowers on fruit trees and in early planted vegetable seedlings and so reduce crop quality. Strong winds could result in loss of livestock and cause soil erosion. For such calamities, there were no traditional predictions mentioned, so science-based ones are needed.

From long-term routine rainfall data, for example the floods that occurred in South Africa in 1975, 1987, 1988, 1995, and 2001 seasons, as well as the droughts that occurred in South Africa in 1963, 1979, 1983, 1997, 1998, and 2002 seasons, elderly participants could recall the years that had these extremes. However, no long-term traditional climate prediction indicators for such events could be mentioned by the farmers. Therefore, traditional rainfall indicators seem to provide only relatively short-term (including seasonal) forecasts/predictions, at least as far as disastrous years are concerned, but very likely more generally as well (see later on Tables 1 and 2 and some of its examples described).

Integration of scientific seasonal predictions with such traditional short term forecasts/predictions could therefore be useful to augment and improve on-farm decision making strategies. Stigter and Winarto found for example that from the scientific seasonal rainfall predictions for Indonesia "most likely seasonal rainfall scenarios" could be derived [36]. That outlook, however, quite often changed on a monthly time scale. However, never, anything in the scientific predictions was shown on an actual start of the rainy or dry seasons in Indonesia. Therefore, validation of early seasonal scenarios with traditional rainfall forecasts/predictions of the start and quality of rainy seasons, as a kind of calibration of the "predicted unknown" by "the familiar traditional", that we also apply to other scientific parameters, became a point of interest in the South-Western Free State. 
Table 1. Months of the year and their role as "forecasting elements" in agricultural timing as used by farmers in the study area before the influence of climate change. The SeSotho/IsiZulu names for these months hold elements of the English description given for each of these twelve months, as derived from interviews with farmers in 2008 and 2012 [1].

\begin{tabular}{|c|c|c|}
\hline Months of the Year & SeSotho/IsiZulu & Agricultural/Meteorological Indication \\
\hline January & Pherekhong/Masingana & $\begin{array}{l}\text { Agricultural activities are highly intense since farmers } \\
\text { are weeding and continuing with } \\
\text { planting of field crops }\end{array}$ \\
\hline February & Hlakula/Nhlolanja & $\begin{array}{l}\text { Most crops are reaching (or are at) maturity stage. In } \\
\text { addition, linked to the preparation of harvesting and } \\
\text { storage stage for the produce }\end{array}$ \\
\hline March & Hlakubele/Ndasa & $\begin{array}{l}\text { Month filled with abundance in agricultural fresh } \\
\text { produce and pasture while the } \\
\text { animals are fattening }\end{array}$ \\
\hline April & Mesa/Mbasa & $\begin{array}{l}\text { Transition in seasonal conditions as the vegetation is } \\
\text { drying up, temperatures are dropping, rains are } \\
\text { becoming lesser and lesser }\end{array}$ \\
\hline May & Motsianong/Nhlaba & $\begin{array}{l}\text { Very cold conditions with noticeable frosts effects, } \\
\text { occurrences of chilling damages in crops }\end{array}$ \\
\hline June & Phupu/Nhlangulana & Discoloration and shedding of leaves from trees \\
\hline July & Phupjane/Ntulikazi & $\begin{array}{l}\text { Severe windy conditions are prominent. First light } \\
\text { rains should be expected that will accelerate } \\
\text { decomposition of crop residues on previously } \\
\text { cultivated land }\end{array}$ \\
\hline August & Phato/Ncwaba & $\begin{array}{l}\text { Seasonal transition from dry to wetter conditions, } \\
\text { budding of trees and other wild plants. The fields are } \\
\text { cultivated }\end{array}$ \\
\hline September & Lwetse/Mandulo & $\begin{array}{l}\text { Regrowth and flowering of certain trees and plants. } \\
\text { First rains beyond what is necessary for preparations of } \\
\text { fields only }\end{array}$ \\
\hline October & Mphalane/Mfumfu & $\begin{array}{l}\text { Certain crops are starting to germinate, } \\
\text { others have germinated and are about } 50 \mathrm{~cm} \text { above } \\
\text { ground }\end{array}$ \\
\hline November & Pulungoana/Lwezi & $\begin{array}{l}\text { Agricultural activities are intensifying as farmers are } \\
\text { engaged with work in the fields and certain insects are } \\
\text { noticed to be producing offspring. }\end{array}$ \\
\hline December & Tsitwe/Zibandlela & $\begin{array}{l}\text { Time of the year when foot paths are fading, due to } \\
\text { grass growth, and families are together cultivating the } \\
\text { land for future consumption }\end{array}$ \\
\hline
\end{tabular}


Table 2. Traditional weather forecasting and climate prediction indicators related to rainfall conditions as derived from interviews with farmers in 2008 and 2012 [1].

\begin{tabular}{|c|c|c|c|}
\hline Indicator & Forecasting/Prediction & Time of Occurrence & Action to be Taken \\
\hline \multirow[t]{4}{*}{$\begin{array}{l}\text { Appearance of } \\
\text { plants }\end{array}$} & $\begin{array}{l}\text { - Above normal blossoming of fruit trees like } \\
\text { peach (Prunus persica) and apricot (Prunus } \\
\text { armeniaca), budding of acacia spp., and other } \\
\text { ornamental trees in the farm surroundings. } \\
\text { Development of young leaves, grass emerging, } \\
\text { sprouting of Aloe ferox in the mountains are } \\
\text { indications of good rains }\end{array}$ & September & $\begin{array}{l}\text { Spring season, prepare for } \\
\text { sowing in November }\end{array}$ \\
\hline & $\begin{array}{l}\text { - Flowering of wild lilies in the veld and } \\
\text { dropping of leaves of fig tree (Ficus carica) } \\
\text { indicate summer is coming }\end{array}$ & September & \\
\hline & $\begin{array}{l}\text { - Dropping of fruits before maturity indicates } \\
\text { very dry season or drought must be expected }\end{array}$ & \multirow[t]{2}{*}{ September/October } & \multirow{2}{*}{$\begin{array}{l}\text { Farmers should consider } \\
\text { drought tolerant crops and } \\
\text { varieties with a shorter } \\
\text { growing season }\end{array}$} \\
\hline & $\begin{array}{l}\text { - Immature fruits drying on trees and/or } \\
\text { dropping from the trees is an indication of } \\
\text { drought }\end{array}$ & & \\
\hline Clouds colour & $\begin{array}{l}\text { Dark clouds are an indication of heavy rainfalls } \\
\text { to occur within a few hours }\end{array}$ & Throughout season & $\begin{array}{l}\text { Always be prepared to } \\
\text { minimize damages that }\end{array}$ \\
\hline \multirow[t]{2}{*}{ Cloud types } & $\begin{array}{l}\text { - Dark clouds preceding strong winds indicates } \\
\text { thunderstorms in few hours }\end{array}$ & & $\begin{array}{l}\text { might occur due to heavy } \\
\text { rains and arrange for roof } \\
\text { water harvesting to be } \\
\text { stored for use as irrigation }\end{array}$ \\
\hline & $\begin{array}{l}\text { - Rainbow colours: red dominating means } \\
\text { more rains to come, if blue color dominates and } \\
\text { clear sky appears it means that rain has passed. } \\
\text { Stratus cloud is a sign for cold days }\end{array}$ & June/July & $\begin{array}{l}\text { Prepare for extreme cold } \\
\text { conditions } \quad \text { (general } \\
\text { knowledge all groups) }\end{array}$ \\
\hline \multirow[t]{2}{*}{$\begin{array}{l}\text { Soil } \\
\text { structure\& its } \\
\text { dryness }\end{array}$} & Soil well moistened tested by hand & October-December & $\begin{array}{lr}\text { Introduce seeds } & \text { or } \\
\text { seedlings under wet } \\
\text { watered soils }\end{array}$ \\
\hline & Soil not well moistened & October-December & $\begin{array}{l}\text { Wait for (late) rainfall } \\
\text { onset }\end{array}$ \\
\hline \multirow[t]{2}{*}{$\begin{array}{l}\text { Appearance of } \\
\text { various insects }\end{array}$} & $\begin{array}{l}\text { - Appearance of red ants and rapidly } \\
\text { increasing size of anthills, which are moist, is } \\
\text { used to predict good rains }\end{array}$ & November/December & $\begin{array}{l}\text { Prepare for (late) sowing } \\
\text { season }\end{array}$ \\
\hline & $\begin{array}{l}\text { - Occurrence of army worms is an indication } \\
\text { of drought to come }\end{array}$ & $\begin{array}{l}\text { Mid-April, July and } \\
\text { early August }\end{array}$ & $\begin{array}{l}\text { Prepare for very dry } \\
\text { season }\end{array}$ \\
\hline \multirow[t]{4}{*}{ Birds } & - First appearance of sparrows & \multirow[t]{4}{*}{ October-March } & \multirow{4}{*}{$\begin{array}{l}\text { Rainy season is at hand, } \\
\text { farmers should prepare for } \\
\text { planting and act to } \\
\text { minimize risk and disaster } \\
\text { that might result from } \\
\text { above normal rains }\end{array}$} \\
\hline & - Flock of swallows proceeding dark clouds & & \\
\hline & - Migration and immigration of birds as a & & \\
\hline & - good sign of rainfall & & \\
\hline
\end{tabular}


Table 2. Cont.

\begin{tabular}{|c|c|c|c|}
\hline Indicator & Forecasting/Prediction & Time of Occurrence & Action to be Taken \\
\hline \multirow[t]{3}{*}{ Moon phases } & $\begin{array}{l}\text { - Moon crescent facing upwards indicates } \\
\text { upholding water and when facing downwards is } \\
\text { releasing rainfall in next three days }\end{array}$ & October-March & \multirow{3}{*}{$\begin{array}{l}\text { Planting time for } \\
\text { vegetables and cash crops } \\
\text { suitable for the area, } \\
\text { farmer should follow } \\
\text { moon phases as control to } \\
\text { the days with and without } \\
\text { rainfall }\end{array}$} \\
\hline & $\begin{array}{l}\text { - moon surrounded by moisture (profuse halo ) } \\
\text { means good rains }\end{array}$ & September/November & \\
\hline & $\begin{array}{l}\text { - First rains should occur before the } \\
\text { appearance of the new moon and then full } \\
\text { moon covered by the clouds indicates good } \\
\text { rains }\end{array}$ & October/November & \\
\hline $\begin{array}{l}\text { Star } \\
\text { constellation }\end{array}$ & $\begin{array}{l}\text { - Star pattern and the movement of stars from } \\
\text { west to east at night under clear skies indicate } \\
\text { onset of rainfall in } 3 \text { days and patterns are also } \\
\text { used to predict cessation of rainfall }\end{array}$ & August-November & $\begin{array}{l}\text { Prepare the land and buy } \\
\text { inputs to plant as it is the } \\
\text { rainy season, select } \\
\text { suitable days, cultivars } \\
\text { and crops to plant }\end{array}$ \\
\hline \multirow{3}{*}{$\begin{array}{l}\text { Animal } \\
\text { behavior } \\
\text { domestic } \\
\text { animals }\end{array}$} & $\begin{array}{l}\text { - Grunting of pigs indicates low humidity and } \\
\text { increase in temperature }\end{array}$ & October to March & $\begin{array}{l}\text { Prepare for agricultural } \\
\text { activities }\end{array}$ \\
\hline & $\begin{array}{l}\text { - Well-fed calves jumping around happily in } \\
\text { the veld and on their way home from grazing in } \\
\text { the mountains and unwilling to graze the } \\
\text { following morning indicates good rains on the } \\
\text { way }\end{array}$ & Throughout season & $\begin{array}{l}\text { Prepare for growing } \\
\text { season with good rains }\end{array}$ \\
\hline & $\begin{array}{l}\text { - Increased libido in goats and sheep with } \\
\text { frequent mating is a sign for good rains }\end{array}$ & $\begin{array}{l}\text { August, September, } \\
\text { October }\end{array}$ & \multirow{3}{*}{$\begin{array}{l}\text { Farmers should engage } \\
\text { themselves into different } \\
\text { agricultural activities from } \\
\text { land preparation, planting } \\
\text { weeding, spraying, etc. }\end{array}$} \\
\hline \multirow[t]{2}{*}{$\begin{array}{l}\text { Appearance of } \\
\text { reptiles }\end{array}$} & $\begin{array}{l}\text { - Certain snakes moving down the mountain } \\
\text { sign of good rains }\end{array}$ & August, September & \\
\hline & $\begin{array}{l}\text { - Frequent appearance of tortoises wandering } \\
\text { around indicates that we should get good rains }\end{array}$ & September-November & \\
\hline Wind swirls & $\begin{array}{l}\text { High frequency in occurrence of wind swirls is } \\
\text { a sign for good rains }\end{array}$ & October/November & $\begin{array}{l}\text { Farmers should prepare } \\
\text { and plant since good rains } \\
\text { are predicted }\end{array}$ \\
\hline Wind direction & $\begin{array}{l}\text { Early in the morning changing direction from } \\
\mathrm{W} \text { to E signal of good rains }\end{array}$ & November-March & $\begin{array}{l}\text { Prepare and plan ahead for } \\
\text { rains to come }\end{array}$ \\
\hline $\begin{array}{l}\text { Mist } \text { covering } \\
\text { hills and } \\
\text { mountains }\end{array}$ & This is a signal for good rains to come & Throughout season & $\begin{array}{l}\text { Ensure that when rain } \\
\text { comes the crops are } \\
\text { already planted and } \\
\text { developing. }\end{array}$ \\
\hline $\begin{array}{l}\text { Atmospheric } \\
\text { temperature }\end{array}$ & $\begin{array}{l}\text { High temperature at night is a sign for good } \\
\text { rains and a long crop growing season, low } \\
\text { temperatures at night is an indication for late } \\
\text { onset of rains and late planting season }\end{array}$ & September-November & $\begin{array}{l}\text { Farmers plan on when to } \\
\text { plant and crop types of a } \\
\text { season to expect }\end{array}$ \\
\hline Water sources & $\begin{array}{l}\text { Drying up of wells, springs, river and wetlands } \\
\text { rapidly is an indication of good rains }\end{array}$ & Spring & $\begin{array}{l}\text { Farmers could prepare for } \\
\text { a good rainy season and } \\
\text { plan their activities in } \\
\text { advance }\end{array}$ \\
\hline
\end{tabular}




\section{Research Methodology, Tools and Techniques [1]}

\subsection{Set $U p$}

Beginning in 2008, local study group workshops and on-farm visits, for discussing weather forecasting, climate prediction and other science-based agrometeorological information, were organized and conducted in the South-Western Free State. This area is also referred to as Modder/Riet catchment, located in the Free State Province, South Africa. The following steps were made for access to the farmers:

$\checkmark$ Step 1. Identification of local informants such as extension agents, for the selection of target groups in the South-Western Free State, to obtain permission to interact with the local producers through extension officers and selection of the target groups.

$\checkmark$ Step 2. Needs analysis in terms of agrometeorological products/advisories/services, methods of knowledge dissemination and traditional weather/climate forecasts/predictions of rainfall through participatory tools and techniques.

$\checkmark$ Step 3. Focus on the existing channels of knowledge exchange of traditional weather/climate forecasts/predictions used by the farmers.

$\checkmark$ Step 4. Farmers were informed on different topics related to agrometeorological products and sharing of weather/climate advisories as an alternative, and good relationships were built with the farmers.

The farmers were randomly selected, based on their availability and willingness to participate in this study at the targeted towns. Workshops with farmers were held on a monthly basis, with study groups in the towns of Brandfort, Koffiefontein, Jakobsdal, Tromsburg, Sannaspos, Ladybrand, Soutpan, Botshabelo, and Thaba-Nchu. The nine communities provide a cross-section of South African farming systems and practices, and more particularly, can offer valuable experiences and observations on traditional weather forecasting and climate predictions. The concept of "field schools" (e.g., [2]) was later on introduced to famers. They were held at the beginning of the planting season as well as at harvesting, while the last one occurred after the installation of two automatic weather stations in Sannaspos. The surveys were conducted to scrutinize the use of agrometeorological products and the existing channels of dissemination.

Qualitative research is a method of inquiry employed in many different academic disciplines, traditionally in the social sciences, but also in market research and further contexts. Qualitative researchers aim to gather an in-depth understanding of human behavior and the reasons that govern such behavior. The qualitative method investigates the why and how of decision making, not just what, where, and when. Hence, smaller but focused samples are more often used than large samples [55]. Qualitative research seemed to be the best research methodology to associate with the farmers' livelihoods and cultural meanings correlated with weather and climate forecasting/predictions. Qualitative research data was collected from individual farmers during on-farm visits, which were conducted concurrently with study groups at the various selected towns. Key informants such as extension agents and in particular commercial and resource poor farmers were identified prior to engaging in the field work. 


\subsection{Experimental Details}

Learning in study groups was a great experience for most farmers, as they used this opportunity to exchange experiences. Agrometeorological knowledge and its application in operational strategic and tactical decision making were introduced during meetings, using questionnaires, with mainly open-ended questions, and group focus discussions. Agrometeorologists have adopted and promoted the use of participatory research tools and techniques as complementary methods, when undertaking agricultural research for development of farmers, as to create a platform for knowledge exchange [13,56].

The study aimed at identifying the gaps in information. During the period of the study, nine preliminary surveys were held, which were followed by inception workshops. We had monthly study group meetings. During these meetings, various participatory tools and techniques were used to exchange data with the farmers. These were structured and semi-structured interviews, off-farm visits and face-to-face engagement, to better understand traditional knowledge used by farmers based on agricultural daily activities and decision making. Informal interviewing was used for rapport establishment and to discover topics of interests relating to weather forecasting and climate predicting. Focus group meetings allowed a good platform for interacting with farmers from different background and to exchange knowledge. Other complementary participatory tools were used to probe for more information and clarity on other issues, from both scientists and farmers. On-farm visits allowed for better understanding of available natural resources and for the assessment of current agricultural status on-farm.

As already hinted at, in meetings with the selected groups of farmers across Modder/Riet catchment, different participatory tools (e.g., [57-59]) were used to exchange knowledge between farmers and researchers. This was done using tools such as focus group discussions during monthly meetings, and questionnaires and techniques, including social and natural resource maps, livelihood maps, time lines, seasonal calendars, Venn diagrams, various matrices, questionnaires (semi-structured and structured), and transect walks [60]. Transect walks were conducted during on-farm visits in the presence of the farm owner(s), to view the status of infrastructure, agricultural practices and natural resources availability per household on-farm [61]. The numbers of transect walks, farm visits, keynote informants, etc., were not recorded.

Additional information from the farmers' perspectives, during the survey, was achieved by semi-structured interviews with the agricultural district officials from the ministry of agriculture, the tribal authorities and local famers. Beside the researchers in agrometeorology, other participants were fire fighters, bank representatives, food processors, animal producers, members of agricultural unions, and successful commercial farmers. Extension agents contributed tremendously in the workshops for the development and provision of support to the farmers. We found that amongst all farmers interviewed, just over $10 \%$ confirmed that they had access to agrometeorological and other science-based products and just below 90\% mentioned that they depended on traditional knowledge and/or their own experience to make decisions. It therefore became even more necessary to discover and learn from farmers' traditional weather forecasting and climate prediction applications.

A total of 394 farmers within the study region participated in our workshops in 2008 and another group of 130 farmers (partly overlapping with the first group) were interviewed in 2012. The groups of 
farmers interviewed and participating in this study consisted of nearly $40 \%$ resource poor farmers and just over $60 \%$ commercial farmers. Amongst all these farmers there were only slightly more than $30 \%$ female farmers, thus, about $70 \%$ male farmers. The groups consisted of $15 \%$ of young farmers, with an age less than 30 years; $25 \%$ were between 30 and 40 years of age, 14\% of farmers aged between 41 to 50 years, and $46 \%$ aged above 50 years. These data may be considered representative for the study region and do not necessarily apply to other regions of the Free State Province or South Africa at large. Where not explicitly mentioned, no distinction was made within groups of farmers between resource poor and commercial farmers.

\section{Results and Discussions}

Below traditional weather forecasts, traditional climate predictions and other traditional weather /climate products are dealt with, using the contents of Tables 1 and 2.

\subsection{General}

During the preliminary survey, as the researchers were assessing the status of the weather/climate knowledge, farmers rather mentioned indigenous indicators than short- or medium-term forecasts/ predictions. They also did not talk about climate change. The authors therefore decided to document and write about this traditional knowledge, as most farmers mentioned their use of a few of these indicators that are related to forecasting/predictions and agricultural activities. No further studies were done to integrate scientific knowledge and local indicators as yet. We used this study just to bring to the farmers some available science-based knowledge for improved decision making and to learn from their traditional knowledge.

The most common traditional indicators across the South-Western Free State are systematically tabulated in Tables 1 and 2, which state indicators used, what they forecast/predict, the time of occurrence and action to be taken at that particular time. As to the terminology used, "good rains" are rains that give a good crop and "poor" rains are rains that do not give a good crop. In both cases, this relates to both: amounts and distributions of rains. However, this will differ with crops.

\subsection{Examples of Trees and Plants as Indicators (See also Table 2)}

The farmers use the budding and flowering of fruit trees and other indigenous plants for weather forecasting and climate prediction. These tree/plant development stages are associated with the onset of spring and summer seasons. Emerging and growth of new leaves from different types of trees are a good indication that temperatures are increasing and the winter season is over. Summer is dominated by mean monthly temperatures of $20{ }^{\circ} \mathrm{C}$ and monthly rainfall above $20 \mathrm{~mm}$ (these data are quoted from [1], where they were obtained from the South African Weather Service). The types of grass and shrubs in the veld that have developed new leaves symbolize the beginning of the planting season. As Table 2 shows, next to cloud types, the behavior of plants is the factor that appears to be most favored by farmers. One of the most prominent indicators of the summer season identified by farmers is the sprouting of the Aloe ferox plant decorating the hills with its orange flowers [62]. Aloe ferox in the South-Western Free State actually does not flower until September, due to colder conditions, whereas 
flowering in warmer areas of South Africa is known to occur between May and August [40]. Aloe ferox is adaptable to many conditions. It means that such traditional forecasting/prediction will keep much of its validity also under conditions of a changing climate [13].

Peach trees (Prunus persica) bloom in early spring, but any drop in temperature below $14{ }^{\circ} \mathrm{C}$, when flowering, tends to kill the blooming flowers [63]. Buds get destroyed between -15 and $-25{ }^{\circ} \mathrm{C}$. Spring frost can be a limiting factor and minimize fruit production [64]. Farmers therefore also associate the flowering of peach with the beginning of the planting season. Apricot trees (Prunus armeriaca) are hardier, less frost sensitive, tolerating winter temperature to $-30{ }^{\circ} \mathrm{C}$ [63]. They flower very early in spring (August to September for South-Western Free State) as they have a chilling requirement. The more abundant blossoming time of peach trees, apricot trees, and other trees in the South-Western Free State, as occurred in September 2008 and 2009, was used by farmers to predict a good rainy season, which also came to pass. It turned out that seasons 2008/2009 and 2009/2010 had good rains in this area, as assessed by these farmers. Another example used by the farmers is the fig tree. Fig trees (Ficus carica L.) have a cold hardiness temperature of -2.2 to $-6.7{ }^{\circ} \mathrm{C}$. The mean suitable temperature is about $18{ }^{\circ} \mathrm{C}$ for budding and flower development [65]. Fig trees flower from spring to autumn, depending on the tree variety.

The types of trees mentioned above require a certain amount of low temperatures to hasten plant development and flowering [63]. The trees have to go through a vernalization period to break dormancy [66,67]. Therefore, low temperatures that occur in July, August, and September play a critical role to initiate the development of buds on trees that results in flowering. Should low temperatures occur when trees blossom or just have blossomed, this might result in flower and fruit damages due to cold conditions [68]. After the trees have flowered, warm temperatures are required to provide thermal time (certain amounts of temperature in degree days) for tree and fruit development throughout the developmental stages until harvesting of fruits. Farmers observe these changes in plant stages [1].

The other most commonly used tree in the South-Western Free State is Faidherbia albida, which is uniquely described in [69] as a tree species with unusual phenology as it sheds its leaves with the rains and is green during the dry season. Its susceptibility to frost favors crop production during the summer season, as the shed leaves are used as mulch which improves soil water content [70,71]. Its tendency of shedding leaves is beneficial to form a good layer of mulch, through its falling litter, at planting time, to improve microclimate and create agroforestry environmental conditions. The amount of pods produced by Faidherbia albida is used by the farmers to predict whether the coming season will be wet or dry. An abundant yield of pods is an indication of a wet season to come and the other way around.

\subsection{Examples of Animals as Indicators (See also Table 2)}

Farmers use the appearance of Mossies or Cape Sparrows (Passer melanurus) as an indication of good rains to come in a day or two. This is of course a purely qualitative assessment by the farmers, including its distribution, based on many years of experience. It serves a decision that they should prepare for field activities [72]. Flocks of sparrows are observed in the South-Western Free State during the growing season, as they feed on seeds and insects. A flock of sparrows flying around the 
sky, with scattered clouds, indicates that there is rain coming in the afternoon. Heavy migration of flocks, merging into widespread formations, resembles and therefore forecasts heavy rains approaching that particular area [73,74]. The occurrence of a heavy flock of birds flying together indicates wind conditions that could be fatal, e.g., convergence [74]. A flock of sparrows leading dark clouds indicates heavy rainfall within approximately an hour. Migration of certain bird species is associated with change of the season in terms of temperature and rainfall [72,74,75]. According to [76], the appearance of birds and insects could assist in detecting meso-scale meteorological phenomena such as gust fronts.

If the herd of cattle is noticed hesitant to go to the veld for grazing, it shows that the rains are to come within a few hours. Other farmers mentioned that cows in the field lie down when the rain is on its way and is coming within a few hours [77]. Whether the calves are sensitive to low pressure systems, high humidities or changes in temperature, is not yet well known [78]. Research on this influence of climatic parameters on calve behavior in Modder/Riet catchment would be helpful, to validate why farmers observe it to forecast rains. Finding scientific reasons for traditional beliefs is advisable throughout, because with cause and effect relationships found, wider and more accurate applications may be found [13].

Farmers become cautious when the snakes are seen more often as they hunt for prey, as it is an indication of the onset of the growing season. Abundant movements of snakes and tortoises are interpreted as the coming of good rainfall, in a seasonal prediction. This, for example, corresponded with a 14 days weather forecast that gave $60 \%-80 \%$ probability of receiving more than $1 \mathrm{~mm}$ of rainfall from the 7-13 February 2008. However, this might well be incidental, because 14 days forecasts are notoriously unreliable (e.g., [79]). At the onset of the summer season in 2008/2009, farmers observed such snakes and tortoises that were busy in the veld and so predicted that good rains were to come. Which then occurred. When certain snakes were observed moving down the mountains, farmers related this active movement of reptiles to seasonal transition from a cold season to a warm season. According to [80], snakes come out of hibernation and down the mountains in search for prey and mating partners to reproduce in early summer season, as the eggs are hatched and baby snakes are produced and fatten their bodies in preparation for the cold season at hibernation. For example, the Rinkhal in our study area appears during spring and early summer and it lives in grassland [80].

Variations in insect population have been shown to exist throughout the seasons of the year $[78,81]$. In the South-Western Free State, the appearance of ants and the mushrooming of anthills occur in the planting season. It for example means that the daily temperatures are warm enough for the ants to come out from hibernation and roam around in/on the soil. In addition, thus, it is also warm enough to plant crops that are sensitive to low temperatures.

\subsection{Examples of Simply the Months as Indicators (Forecasting Elements) (See also Table 1)}

For basics, farmers everywhere traditionally simply depended on the months of the year to determine the agricultural activities to be implemented. Table 1 shows this around the year for the study area as obtained from interviews with farmers in 2008 and 2012 [1]. According to the farmers in South-Western Free State, it appears that the last week of July (and sometimes even an earlier period in that month) is well-known to bring first rains, which are meant to assist in further decomposing crop residues, which enhances soil nutrient status, thus, soil fertility. 
Commercial farmers also should get the tractors ready for land preparation. August symbolizes the month for first plowing to occur, which is aimed at turning over the soil to minimize the spread of weeds and insects. Commercial farmers in the South-Western Free State were observed to cultivate the land in late July and after the August rains in 2008 and 2009, in line with the traditional farming. Farmers plow the fields and then wait for September rains to transplant seedlings obtained from local nurseries or produced from on-farm plastic tunnels. Those who do not plant vegetables will disc the land to prepare for November planting of maize, sunflower, and sorghum. According to rainfall data analysis for the study area, monthly mean rainfall shows that an onset sufficient for resuming agricultural activities beyond the above preparations starts in the month of September, with above $25 \mathrm{~mm}$ of rains to be expected [1].

Rains then reach a peak of about $80 \mathrm{~mm}$ in January and subsequently decrease to about $40 \mathrm{~mm}$ in April. Therefore, months of the year as a general traditional climate prediction indicator for rainfall were backed by such rainfall observations [1]. These observations were useful from a farming point of view, but they were more so before climate change started to make its impacts (e.g., [13]). Stigter and Winarto found that climate change and problems of water management related to seasonal changes are slowly but clearly compromising this rainfall seasonality and periodicity knowledge in Indonesia [2]. This is confirmed by our most recent experience in South Africa and is seen as a general trend throughout the world [82].

\subsection{Examples of Other Traditional Indicators (See also Table 2)}

One other indicator used by farmers is a soil material characteristic. As it makes a ball, it means that there is sufficient water in the soil. If the soil does not have sufficient water, it crumbles and falls apart. This is a method used to test the wetness of the soil. When soil is saturated, all air spaces are full of water, but as the gravitational water drains out, the soil reaches field capacity, where plants are able to draw water till wilting point is reached. It is near field capacity when the soil forms a ball without water being squeezed out.

The appearance of the crescent moon facing up is a traditional rainfall indicator, which is reasoned as follows. If the crescent appears facing upwards, it means that it can hold rainfall; while as the crescent appears face down, it is an indication of releasing rainfall to mother earth and rainfall should be expected within three days. Farmers across the region also commented that good chances of rainfall are expected around the date of the new moon but that, in contrast, full moon is usually associated with lower rainfall chances. If a poor rain event occurs at the time of the new moon, the following months are expected to be dry. Good rains at new moon indicate that the following month will be wet. Farmers have used moon phases for planting decisions for many decades, possibly centuries. The waxing of the moon is the recommended time to plant leafy vegetables and flowers, and transplant seedlings. The waning of the moon is an indication to plant underground crops, e.g., potatoes, sweet potatoes, groundnuts, and control weeds and thin the plants [83,84].

Farmers also mentioned the techniques of using star patterns and movements to predict rainfall onset, days to expect rainfall and rainfall cessation (compare [85] for Asia). However, the farmers could not explain exactly how it works. As the moon phases and its orbit around the earth affect the rising and falling tides, air currents, and the occurrence of thunderstorms [83], it is observed that this 
indigenous knowledge may be related to scientific logic. Whether the use of moon phases and the star constellation actually has a relationship to rainfall or not, farmers in the South-Western Free State are confident that it works well as a predictive tool for rainfall and the agricultural activities to consider for different seasonal conditions. Here again scientific research would be helpful, particularly while climate change may influence any of these relationships [13].

Dark cloud appearance is well known as an indicator for good rains coming within a few hours. Where the cloud appearance is related to the coming of rains, also this traditional climate indicator could be kept to be related to scientific reasoning. For example, even the 14 days predictions of [86] represent cloud cover and use probabilities to predict the chances of getting certain amounts of rain. This prediction, however, is in need of large scale validation in different parts of South Africa.

Farmers from all study groups reported wind direction as another indicator used to forecast heavy rainfall. Farmers strongly believe in observing the wind direction to predict the onset of rainfall. Farmers use westerly winds to forecast rains within a few days. However, further research to determine more scientific explanations for these indicators would be necessary and helpful before they can be introduced with their full scientific understanding [13]. A complete review of what farmers brought up is in Table 2.

\subsection{Disadvantages and Advantages According to Farmers}

For the farmers to learn about and confidently adopt science-based knowledge, they were tasked to discuss the advantages and disadvantages of using traditional as well as science-based weather/climate forecasts/predictions indicators/knowledge. It appeared that this exercise was not the easiest, as it raised lots of disagreement amongst the farmers. This led to different opinions from different experiences. Eventually, the farmers were able to draw some conclusions regarding this matter. They identified and listed the following statements as disadvantages of traditional weather/climate forecasts/predictions and disadvantages of science-based weather/climate forecasts/predictions (Table 3). Thus, the farmers were not yet able to clearly give advantages as we were not yet following the use of various science-based messages and their influence on production parameters (see [2] for this issue in Indonesia). That is one of the themes for follow-up research, where also the extension has to become better involved.

The best outcome of this research was that farmers and scientists learnt new things and shared their knowledge and experience. We agree with [87] that scholars have wasted too much time and effort on a science versus traditional knowledge debate; we should reframe it instead as a science and traditional knowledge dialogue and partnership (see also [2,13]). In the light of the importance of conservation issues, we know that conservation action can be based on traditional knowledge and values, or a resurgence of these values [87]. We also know that indigenous community conserved areas are often based on multiple objectives, including sustainable use and livelihood needs, cultural value, self-governance, and economic development, as well as for biological conservation [87]. We need more and deeper partnerships of traditional knowledge and science to solve conservation problems, strengthen the network of community conserved areas, engage in ecosystem-based management, set up cross-cultural monitoring for environmental change, and carry out ecological restoration that responds to community needs [87] (see also [13]). 
Table 3. Disadvantages of using traditional weather/climate forecasts/predictions and disadvantages of using science-based weather/climate forecasts/predictions as derived from interviews with farmers in 2008 and 2012 [1].

\begin{tabular}{|c|c|}
\hline $\begin{array}{l}\text { Disadvantages of Traditional Weather/Climate } \\
\text { Forecasts/Predictions }\end{array}$ & $\begin{array}{l}\text { Disadvantages of Science-Based Weather/Climate } \\
\text { Forecasts/Predictions }\end{array}$ \\
\hline $\begin{array}{l}\checkmark \text { They are only momentary but it can work well when } \\
\text { combined with scientific forecasts/predictions, } \\
\checkmark \quad \text { They are culture-based and interpreted differently for } \\
\text { different areas, } \\
\checkmark \quad \text { They do not provide predictions on the not immediate } \\
\text { future, some seasonal indications apart, } \\
\checkmark \quad \text { They cannot predict mid-season dry spells or their } \\
\text { probabilities, } \\
\checkmark \quad \text { They do not indicate rainfall distributions but only } \\
\text { when to prepare for the onset and sometimes something } \\
\text { on the quality of the season to come, } \\
\checkmark \text { They are not trusted by some scientific } \\
\text { forecast/prediction producers as they, incorrectly, } \\
\text { perceive it as based on superstition. }\end{array}$ & $\begin{array}{l}\checkmark \quad \text { They are not easily available and accessible } \\
\text { for use in agriculture, } \\
\checkmark \quad \text { Their advantages are not documented in ways } \\
\text { that farmers can understand, } \\
\checkmark \quad \text { They are difficult to interpret and it is not } \\
\text { easy to make decisions based on the } \\
\text { probabilistic information given, } \\
\checkmark \quad \text { They are not point specific and there is a } \\
\text { need for trustable downscaled } \\
\text { weather/climate forecasts/predictions. }\end{array}$ \\
\hline
\end{tabular}

This must be part of the beneficial learning by scientists. Through the process of interacting with other farmers, our farmers learnt and steadily adapted the application of weather/climate products and other science-based agrometeorological knowledge for agricultural decision making. This farmer-to-farmer extension should be recommended and encouraged for reaching the highest number of farmers in an area, towards understanding of advisories and appreciation of agrometeorological services in their fields (see also [36]).

\section{Conclusions and Recommendations}

The traditional knowledge and its use reported on in this paper, is what scientists learned from farmers. There is a need for follow-up research to look more deeply at local indicators versus climate change and possible integration of scientific knowledge and local knowledge. Farmers use weather and climate related indicators in their traditional forecasts/predictions, mostly of immediate or seasonal rains and droughts. Agricultural decisions are made according to traditional knowledge and understanding of these environmental conditions of their local area, obtained through years of experience. Understanding of the farmers' perceptions of weather and climate is a critical step to facilitate effective communication on science-based agrometeorological knowledge. This learning is necessary for scientists.

During interactions with the farmers it became obvious that long before the existence of modern scientific methods for weather forecasting and climate prediction, farming with relatively low yields continued successfully with the exception of regular disasters. However, training on the application of science-based agrometeorological advisories/services such as on crop suitability, cultivar selection, planting date, planting density, weeding, water management, pests and diseases, fertilizing, etc., is 
recommended for guiding farmers in improved decision-making for higher yields. An ecological approach may be added.

This research revealed that most traditional farmers in the South-Western Free State were not familiar with the application of external weather forecasts/climate predictions for agriculture and other science-based agrometeorological/-climatological products where they exist. It must be concluded that until recently they relied only on their own experience and traditional knowledge for farming decision-making. Our findings are a strong indication to agricultural scientists that some well-researched scientific knowledge and some still insufficiently researched scientific knowledge can benefit traditional farmers' decision making but does not reach these farmers in any usable form. Therefore, farmers can only use what is available to them. Most commercial farmers, having more resources, as well as a more formal education, performed better and had more knowledge and more access to science-based knowledge compared to the resource-poor farmers.

Farmers in the South-Western Free State regularly experience devastating disasters that are weather and climate related, such as rainfall scarcity and irregularity, floods, untimely frost events, severe winds that also continue and intensify destructive wildfires, outbreaks of diseases and pests, difficult to control weeds, which require intensive labor, as well as severe drought conditions and overgrazed grazing lands posing dangers of desertification. The participating farmers realized from slowly improving yields that science-based early warnings, weather/climate related forecasts/predictions and other science-based agrometeorological advisories/services are able to protect farmers better than their traditional knowledge could, by new knowledge-based preparedness and decision making.

This statement is validated from the limitations of traditional knowledge but not yet quantitatively/scientifically proven from what farmers actually applied. This must be done in follow-up research. This is true, notwithstanding the disadvantages that farmers mentioned to exist, but this new knowledge should be much improved, taking note of what causes these disadvantages. Researchers engaged in such improvements should incorporate sociology/anthropology and farm management approaches, with participatory tools, in knowledge exchange and dialogues with and support of the farmers (see also [2,36]).

During the study groups, on-farm meetings and field schools, farmers demonstrated a great eagerness to learn about science-based agrometeorological information/advisories/services. This study can recommend that participatory interaction with the farmers using focus groups, buzz questions, word of mouth, study groups, and workshops allows two-way participation. This helps to understand the user's perception of the advisories; it allows a platform for constructive criticism that should lead to improvement of products. Exchange of knowledge took already place since farmers shared their knowledge on traditional forecasting and decision making. It is therefore recommended that, through such meetings, a permanent platform to exchange knowledge is created to build permanent dialogues with the farmers. This results in a dual learning process. Training of intermediaries on climate change as well as social science issues is a necessity for interacting with the farmers when addressing the application of science-based agrometeorological advisories and services (see also [36]).

Integration of agrometeorological products with local knowledge on weather forecasting and climate prediction may improve adaptation strategies and ensure that new knowledge, products, and services are implemented at farm level. Therefore, validation of early seasonal scenarios with traditional rainfall forecasts/predictions of the start and quality of rainy seasons, as a kind of calibration of the 
"predicted unknown" by the "familiar traditional", that we also apply to other scientific parameters, became a point of interest in the South-Western Free State.

The best outcome of this research was that farmers and scientists learnt new things and shared their knowledge and experience. Berkes [87] was right that scholars have wasted too much time and effort on a science versus traditional knowledge debate; we should reframe it instead as a science and traditional knowledge dialogue and partnership. The complications of a changing climate make this even more necessary. Through the process of interacting with other farmers, farmers learnt and steadily adapted the application of weather/climate products and other science-based agrometeorological knowledge for agricultural decision making. This farmer-to-farmer extension should be recommended and encouraged for reaching the highest number of farmers in an area, towards understanding of advisories and appreciation of agrometeorological services in their fields (see also [36]).

\section{Acknowledgements}

Authors would like to send a word of appreciation to all the farmers in the South-Western Free State who participated and made contributions to this study. We are grateful for the support of all study group coordinators and the district extension agents for their valuable assistance to work, train and exchange knowledge with the farmers. The work was supported by the Water Research Commission, the Agricultural Research Council and the University of the Free State. The authors thank C.C. du Preez, Head of the Department of Soil, Crop and Climate Sciences of the Free State University, for his particular interest taken in the work of Zuma-Netshiukhwi and his special support given to her thesis efforts. The authors also want to express their appreciation to two anonymous reviewers for their valuable suggestions to improve this paper.

\section{Conflicts of Interest}

The authors declare no conflict of interest.

\section{References}

1. Zuma-Netshiukhwi, G.N. The Use of Operational Weather and Climate Information in Farmer Decision Making, Exemplified for the South-Western Free State, South Africa. Ph.D. Thesis, University of the Free State, Bloemfontein, South Africa, 2013.

2. Stigter, C.(K.)J.; Winarto, Y.T. Science Field Shops in Indonesia. A start of improved agricultural extension that fits a rural response to climate change. J. Agric. Sci. Appl. 2013, 2, 112-123.

3. Shumba, O. Coping with Drought: Status of Integrating Contemporary and Indigenous Climate/Drought Forecasting in Communal Areas of Zimbabwe; Consultancy Report to the United Nations Development Program Office to Combat Desertification and Drought; UNSO/UNDP/WMO: Harare, Zimbabwe, 1999.

4. Cultivating Knowledge, Genetic Diversity, Farmer Experimentation and Crop Research; De Boef, W., Amanor, K., Wellard, K., Bebbington, A., Eds.; Intermediate Technology Publications: London, UK, 1993. 
5. Stigter, C.J. Shading: A traditional method of microclimate manipulation. Neth. J. Agric. Sci. 1984, 32, 81-86.

6. Stigter, C.J. Examples of mulch use in microclimate management by traditional farmers in Tanzania. Agric. Ecosyst. Environ. 1984, 11, 173-176.

7. Stigter, C.J. Tapping into traditional knowledge. African revival. Rediscovering their own resources (centrepiece papers). CERES FAO Rev. 1987, 20, 29-32.

8. Gadgil, M.; Berkes, F.; Folke, C. Indigenous knowledge for biodiversity conservation. Ambio 1993, 22, 151-156.

9. Biodiversity and Traditional Knowledge; Laird, S., Ed.; Earthscan: London, UK and Sterling, VA, USA, 2002.

10. Shiferaw, T.; Lamond, G.; Gebrekirstos, A.; Meles, K.; Aynekulu, E.; Hachoofwe, E.M.; Mowo, J.; Garrity, D.; Sinclair, F. Recognizing Local Agro-Ecological Knowledge in Sustainable Intensification of Tree-Crop-Livestock Farming Systems; World Agroforestry Centre: Nairobi, Kenya, 2013.

11. Agrometeorological Learning: Coping Better with Climate Change; Winarto, Y.T., Stigter, K., Eds.; LAP LAMBERT Academic Publishing GmbH \& Co. KG: Saarbrucken, Germany, 2011.

12. Camberlin, P. Rainfall anomalies in the source of the Nile and their connection with the Indian Summer Monsoon. J. Clim. 1997, 10, 1380-1392.

13. Applied Agrometeorology; Stigter, K., Ed.; Springer: Heidelberg/Berlin, Germany and New York, NY, USA, 2010.

14. Green, D.; Raygorodetsky, G. Indigenous knowledge of a changing climate. Climat. Chang. 2010, 100, 239-242.

15. Frankema, E. Africa and the Green Revolution: A Global Hisotrical Perspective; Wageningen University: Wageningen, The Netherlands, 2013.

16. Hart, T.G.B. Local knowledge and agricultural application: Lessons from an Ugandian parish. S. Afr. J. Agric. Ext. 2007, 36, 229-268.

17. Garay-Barayazarra, G.; Puri, R. Smelling the monsoon: Senses and traditional weather forecasting knowledge among the Kenyah Badeng Farmers of Sarawak, Malaysia. Ind. J. Trad. Knowl. 2011, $10,21-30$.

18. Merchant, M.E.; Flanders, R.V.; Williams, R.E. Seasonal abundance and parasitism of house fly (Diptera: Muscidae) pupae in enclosed, shallow-pit poultry houses in Indiana. Environ. Entomol. 1987, 16, 716-721.

19. Olbrich, D.L.; King, B.H. Host and habitat use by parasitoids (Hymenoptera Pteromalidae) of house fly and stable fly (Diptera Muscidae) pupae. Great Lakes Entomol. 2003, 36, 179-190.

20. Prendergast, H.D.V.; Davis, S.D.; Way, M. Dryland Plants and Their Uses. In Spiritual Values of Biodiversity; Posey, D.A., Ed.; Intermediate Technology Publications: London, UK, 1999; pp. 233-235.

21. Dunn, R.R. Poetic entomology: Insects in Japanese haiku. Am. Entomol. 2000, 46, 70-72.

22. Kihupi, N.; Kingamkono, R.; Dihenga, H.; Kingamkono, M.; Rwamugira, W. Integrating Indigenous Knowledge and Climate Forecasts in Tanzania. In Coping with Climate Variability: The Use of Seasonal Climate Forecasts in Southern Africa; O’Brien, K., Vogel, C., Eds.; Ashgate Publishing Ltd.: Hampshire, UK and Burlington, VT, USA, 2003; pp. 155-169. 
23. Osbahr, H.; Dorward, P.; Stern, R.; Cooper, S. Supporting agricultural innovation in Uganda to respond to climate risk: Linking climate change and variability with farmer perceptions. Exp. Agric. 2011, 47, 293-316.

24. Orlove, B.; Roncoli, C.; Kabugo, M.; Majugu, A. Indigenous climate knowledge in southern Uganda: The multiple components of a dynamic regional system. Climat. Chang. 2010, 100, 243-265.

25. Stigter, C.J.; Dawei, Z.; Onyewotu, L.O.Z.; Xurong, M. Using traditional methods and indigenous technologies for coping with climate variability. Climat. Chang. 2005, 70, 255-271.

26. Meinke, H. Adaptation Science for Agriculture: Solutions for a Changing Planet; Wageningen University: Wageningen, The Netherlands, 2010.

27. Sivakumar, M.; Hansen, J.W. Climate Prediction and Agriculture: Summary and the Way Forward. In Climate Prediction and Agriculture: Advances and Challenges; Sivakumar, M., Hansen, J.W., Eds.; Springer: Berlin, Germany, 2007.

28. Ogindo, H.O.; Walker, S. Comparison of measured changes in seasonal soil water content by rain-fed maize-bean intercrops and component cropping systems in a semi-arid region of southern Africa. Phys. Chem. Earth 2005, 30, 799-808.

29. Wamukonya, N.; Rukato, H. Climate Change Implications for Southern Africa: A Gendered Perspective. Available online: http://www.energia.org/fileadmin/files/media/pubs/ wamukonyarukato.pdf (accessed on 2 June 2013).

30. Kalanda-Joshua, M.; Ngongondo, C.; Chipeta, L.; Mpembeka, F. Integrating indigenous knowledge with conventional science: Enhancing localized climate and weather forecasts in Nesa, Malunje, Malawi. Phys. Chem. Earth 2011, 36, 996-1003.

31. Ziervogel, G. Targeting seasonal climate forecasts for integration into household level decisions: The case of smallholder farmers in Lesotho. Geogr. J. 2004, 170, 6-21.

32. Patt, A.; Gwata, C. Effective seasonal climate forecast applications: Examining constraints for subsistence farmers in Zimbabwe. Glob. Environ. Chang. 2002, 12, 185-195.

33. Stigter, C.(K.)J.; Ofori, E. What climate change means for farmers in Africa. A triptych review. Left panel: Increasing climate variability and a response approach for African farmers. Afric. $J$. Food Agric. Nutr. Dev. (AJFAND) 2013, in press.

34. Stigter, C.(K.)J.; Ofori, E. What climate change means for farmers in Africa. A Triptych Review. Right Panel: Climate extremes and society's responses, including mitigation attempts as part of preparedness of African farmers. Afric. J. Food Agric. Nutr. Dev. (AJFAND) 2013, in press.

35. Simelton, E.; Quinn, C.H.; Batisani, N.; Dougill, A.J.; Dyer, J.C.; Fraser, E.D.G.; Mkwambisi, D.; Sallu, S.; Stringer, L.C. Is rainfall really changing? Farmers' perceptions, meteorological data, and policy implications. Clim. Dev. 2013, 5, 123-138.

36. Stigter, K.; Winarto, Y.T.; Ofori, E.; Zuma-Netshiukhwi, G.N.; Nanja, D.; Walker, S. Extension agrometeorology as the answer to stakeholder realities: Response farming and the consequences of climate change. Special Issue on Agrometeorology: From Scientific Analysis to Operational Application. Atmosphere 2013, 4, 237-253.

37. Röling, N.; Hounkonnou, D.; Kossou, D.; Kuyper, T.W.; Nederlof, S.; Sakyi-Dawson, O.; Traore, M.; van Huis, A. Diagnosing the scope of innovation: Linking smallholder practices and 
institutional context. Introduction to the special issue. NJAS-Wageningen J. Life Sci. 2012, 60-63, $1-6$.

38. Yemadje, R.H.; Crane, T.A.; Vissoh, P.V.; Mongbo, R.L.; Richards, P.; Kossou, D.K.; Kuyper, T.W. The political ecology of land management in the oil palm based cropping system on the Adja plateau in Benin. NJAS-Wageningen J. Life Sci. 2012, 60-63, 91-99.

39. O’Brien, K.; Leichenko, R.; Kelkar, U.; Venema, H.; Aandahl, G.; Tompkins, H.; Javed, A.; Bhadwal, S.; Barg, S.; Nygaard, L.; et al. Mapping vulnerability to multiple stressors: Climate change and globalizat ion in India. Glob. Environ. Chang. 2004, 14, 303-313.

40. O'Brien, K.; Eriksen, S.; Schjolden, A.; Nygaard, L.P. What's in a Word? Conflicting Interpretations of Vulnerability in Climate Change Research; CICERO Working Paper 2004:04; Center for International Climate and Environmental Research: Oslo, Norway, 2009.

41. Vasquez-Leon, M.; West, C.T.; Finan, T.J. A comparative assessment of climate vulnerability: Agriculture and ranching on both sides of the US-Mexico border. Glob. Environ. Chang. 2003, 13, 159-173.

42. Dudgeon, R.C.; Berkes, F. Local Understandings of the Land: Traditional Ecological Knowledge and Indigenous Knowledge. In Nature Across Cultures: Views of Nature and the Environment in Non-Western Cultures; Selin, H., Ed.; Kluwer Academic Publishers: London, UK, 2003; pp. 75-96.

43. Berkes, F.; Colding, J.; Folke, C. Rediscovery of traditional ecological knowledge as adaptive management. Ecol. Appl. 2000, 10, 1251-1262.

44. Tittonell, P.A. Towards Ecological Intensification of World Agriculture. Available online: http://www.wageningenur.nl/en/show/Towards-ecological-intensification-of-world-agriculture.htm (accessed on 5 July 2013).

45. Ristroph, E.B. Integrating Community Knowledge into Environmental and Natural Resource Decision-Making: Notes from Alaska and around the World. Available online: http://works.bepress.com/elizabeth_ristroph/2 (accessed on 2 August 2013).

46. Homepage of Professor Henrik Möller. Available online: http://www.otago.ac.nz/csafe/staff/ otago038810.html (accessed on 2 August 2013).

47. Crane, T.A.; Roncoli, C.; Paz, J.; Breuer, N.E.; Broad, K.; Ingram, K.T.; Hoogenboom, G. Seasonal Climate Forecasts and Risk Management Among Georgia Farmers. In Southeast Climate Consortium Technical Report Series SECC-08-003. Available online: http://www.seclimate.org/ pdfpubs/SECC_08_003.pdf (accessed on 26 July 2013).

48. Berliant, M.; Fujita, M. Dynamics of knowledge creation and transfer: The two person case. Int. J. Econ. Theory 2009, doi: 10.1111/j.1742-7363.2009.00104.x.

49. Dixon, J.; Gulliver, A.; Gibbon D. Farming Systems and Poverty. Improving Farmers' Livelihoods in a Changing World. Available online: http://www.fao.org/docrep/003/y1860e/ y1860e00.htm (accessed on 25 February 2013).

50. Tadross, M.; Jack, C.; Hewitson, B. On RCM-based projections of change in southern African summer climate. Geophs. Res. Lett. 2005, 32, L23713.

51. Zuma-Netshiukhwi, G.N.; Beinzonhuit, R. Indigenous knowledge on rainfall forecasting. Farm. Wkly. 2008, 4/5, 22-23. 
52. Kahn, M.F. Two measures of progress in adapting to climate change. Glob. Environ. Chang. 2003, 13, 307-312.

53. Stigter, C.(K.)J.; Ofori, E. What climate change means for farmers in Africa. A Triptych Review. Middle Panel: Introductional matters and consequences of global warming for African farmers. Afric. J. Food Agric. Nutr. Dev. (AJFAND) 2013, in press.

54. Okoola, R.E. Space-time Characteristics of ITCZ over Equatorial Eastern Africa during Anomalous Rainfall Years. Ph. D. Thesis, University of Nairobi, Nairobi, Kenya, 1996.

55. Qualitative Research. Available online: http://en.wikipedia.org/wiki/Qualitative_research (accessed on 11 August 2013).

56. Grenier, L.A. Working with Indigenous Knowledge: A Guide for Researchers; International Development Research Center: Ottawa, ON, Canada, 1998.

57. Kramer, R. Leading change through action learning. Publ. Manag. 2007, 36, 38-44.

58. Serrat, O. Action Learning. Knowl. Solut. 2008, 19, 1-3.

59. Kelman, I.; Mercer, J.; West, J.J. Chapter 2. Combining Different Knowledges: Community-Based Climate Change Adaptation in Small Island Developing States. In Participatory Learning and Action 60-Community-Based Adaptation to Climate Change. Available online: http://pubs.iied.org/pdfs/G02812.pdf (accessed on 15 June 2013).

60. Zhu, X.; Dale, A.P. Identifying opportunities for decision support systems in support of regional resource use planning: An approach through soft systems methodology. Environ. Manag. 2000, 26, 371-384.

61. Collier, N.; Mackay, D.A.; Benkendorff, K.; Austin, A.D.; Carthew, S.M. Butterfly communities in South Australian urban reserves: Estimating abundance and diversity using the Pollard walk. Austr. Ecol. 2006, 31, 282-290.

62. Glen, H.F.; Hardy, D.S. Aloaceae (First Part): Aloe. In Flora of Southern Africa; Germishuizen, G., Ed.; National Botanical Institute: Clermont, South Africa, 2000; Volume 5; pp. 1-167.

63. Naik, A. Peach Tree Care; 2010. Available online: www.buzzle.com.article/peach-tree-care.html (accessed on 15 September 2010).

64. Gradziel, T.M.; McCaa, J.P. Processing Peach Cultivar Development. In The Peach: Botany, Production and Uses; Layne, D.R., Bassi, D., Eds.; CAB Int.: Wallingford, CT, USA, 2008.

65. Piga, A.; Pinna, I.; Ozer, K.B.; Agabbio, M.; Aksoy, U. Hot air dehydration of figs (Ficus carica L.): Drying kinetics and quality loss. Int. J. Food Sci. Technol. 2004, 39, 793-799.

66. Michael, S.D.; He, Y.; Scortecci, K.C.; Amasino, R.M. Attenuation of FLOWERING LOCUS C activity as a mechanism for the evolution of summer-annual flowering behavior in Arabidopsis. Proceed. Nat. Acad. Sci. USA 2003, 100, 10102-10107.

67. Chouard, P. Vernalization and its relations to dormancy. Ann. Rev. Plant Physiol. 1960, 11, 191-238.

68. Amasino, R.M. Vernalization and flowering time. Curr. Opin. Biotechnol. 2005, 16, 154-158.

69. Coates Palgrave, K. Trees of Southern Africa, 3rd ed.; Struik Publishers: Cape Town, South Africa, 2002.

70. Dommergues, Y.R. Nitrogen fixation by trees in relation to soil nitrogen economy. Fert. Res. 1995, 42, 215-230.

71. Sanchez, P.A. Science in agroforestry. Agrofor. Syst. 1995, 30, 5-55. 
72. De Swardt, D.H.; Grobler, G.P.J.; Oschadleus, H.D. Bird ringing in the Free State National Botanical Gardens, Bloemfontein, with notes on recaptures. Afring News 2004, 33, 65-70.

73. Eastwood, E. Radar Ornithology; Methuen and Co.: London, UK, 1967.

74. Koistinen, J. Bird migration patterns on weather radar. Phys. Chem. Earth 2000, 25, 1185-1193.

75. Kopij, G. Birds of Ooseinde and Bloemspruit sewage dams, Bloemfontein. Mirafra 2002, 19, 2-7.

76. Anderson, D.; Eriksson, L.O. Effects of temporal aggregation in integrated strategic/tactical and strategic forest planning. For. Pol. Econ. 2007, 9, 965-981.

77. Berkeley, E.V.; Linklater, W.L. Annual and seasonal rainfall may influence progeny sex ratio in the Black Rhinoceros. S. Afr. J. Wildl. Res. 2010, 40, 53-57.

78. Changa, L.B.; Yanda, P.Z.; Ngana, J. Indigenous knowledge in seasonal rainfall prediction in Tanzania: A case of the south-western Highland of Tanzania. J. Geogr. Regl. Plann. 2010, 3, 66-72.

79. Gardner, D. Future Babble: Why Expert Predictions Fail and Why We Believe them Anyway; Virgin Books: London, UK, 2011.

80. Marais, J. What's That Snake? A Starter's Guide to Snakes of Southern Africa; Struik Publishers: Cape Town, South Africa, 2008.

81. Lowman, M.D. Seasonal Variation in Insect Abundance among Three Australian Rain Forests, with Particular Reference to Phytophagous Types. Available online: www.canopymeg.com/PDFs/ papers/005.pdf (accessed on 17 March 2008).

82. Jennings, S.; Magrath, J. What Happened to the Seasons? OXFAM Research Report. Available online: http://www.oxfam.org.uk/resources/policy/climate_change/downloads/research_what _happened_to_seasons.pdf (accessed on 1 June 2013).

83. Crawford, E.A. The Lunar Garden: Planting by the Moon Phases; Weidenfeld \& Nicholson: New York, NY, USA, 1989.

84. O'mahony, G. Rainfall and moon phases. Quart. J. Roy. Meteorol. Soc. 2006, 91, 196-207.

85. Stigter, C.J.; Winarto, Y.T. Considerations of climate and society in Asia (I) What climate change means for farmers in Asia. Earthzine 2012, 4. Available online: http://www.earthzine.org/2012/ 04/04/what-climate-change-means-for-farmers-in-asia/ (accessed on 6 April 2012).

86. South African Weather Service (SAWS). Available online: www.weathersa.co.za/freestate (accessed on 12 March 2009).

87. Berkes, F. Indigenous ways of knowing and the study of environmental change. J. Roy. Soc. N. Z. 2009, 39, 151-156.

(C) 2013 by the authors; licensee MDPI, Basel, Switzerland. This article is an open access article distributed under the terms and conditions of the Creative Commons Attribution license (http://creativecommons.org/licenses/by/3.0/). 